drawn to the difference in expression employed by Proclus, viz. that Euclid arranged many works of Eudoxus, and completed many of those of Thertetus, from which Dr. Allman infers that, "whereas the bulk of the fifth and twelfth books is due to Eudoxus; on the other hand, Thertetus laid the foundation only of the doctrine of incommensurables as treated in the tenth book. In like manner from $(f)$ we infer that the thirteenth book, treating of the regular solids, is based on the theorems discovered by Theretetus; but it contains, probably, a recapitulation, at least partial, of the work of Aristæus" [cf. NATURE, $u b i$ supra].

The author, in conclusion, draws the inference that the principal part of the original work of Euclid himself is to be found in the tenth book. "De Morgan suspected that in this book some definite object was sought, and suggested that the classification of incommensurable quantities contained in it was undertaken in the hope of determining thereby the ratio of the circumference of the circle to its diameter, and thus solving the vexed question of its quadrature. It is more probable, however, that the object proposed concerned rather the subject of Book xiii., and had reference to the determination of the ratios between the edges of the regular solids and the radius of the circumscribed sphere, ratios which in all cases are irrational. In this way is seen, on the one hand, the connection which exists between the two parts of the work of Theretetus, and, on the other, light is thrown on the tradition handed down by Proclus, that Euclid proposed to himself the construction of the so-called Platonic bodies as the final axiom of his systematization of the "Elements." " Here for the present I take leave of the author. I have read his several parts as they have appeared with very great interest, and have endeavoured, without going far into technical details, to indicate the results arrived at, and I hope that some will have been induced to go to the fountain-head for undiluted draughts from this refresh ing stream. I need only repeat the expression of the wish, more than once previously uttered, that the several papers may be collected into a handy volume, in which case they will fitly go side by side with the works of Bretschneider, Cantor, Tannery, and other distinguished labourers in the same field. R. T.

\section{The Chromosphere.}

Having lately devised a spectroscope with two small sextant telescopes and two small prisms, one of "extra dense" glass by Hilger, I attached it to a $2 \frac{1}{2}$-inch telescope, and tried its powers on the sun on the 6th inst., with the result that not only were the rays $C$ and $D^{3}$ easily visible as bright lines, but I also found that by opening the slit and keeping the brighter part of the spectrum out of view I could see the actual ragged surface of the "torm-tossed sea of hydrogen."

I found the depth of the chromosphere to be about $\mathrm{IO}^{\prime \prime}$, by estimating the length of the bright line when exactly tangential to the limb.

This result shows what is possible with small instrumental means, though probably much was due to an exceptionally clear sky. JOHN EVERShrd, JUN.

\section{Perception of Colour.}

IN answer to Mr. T. W. Backhouse, I would suggest that he should use the spectro cope in the following manner. Hold it between the luminous object (moon or street lamp) and the eye at a distance of about $\mathbf{1} 2$ or 15 inches from the latter, so that only part of the spectrum is seen. Then remove the spectroscope sideways, and pass it quickly through its old position. A flash of coloured light will be seen, and no matter what may be the direction of the spectrum with reference to the line of motion the flash will always be seen to travel from the red end towards the blue end. Each part of the spectrum can be examined separately.

Whether this phenomenon is due to a later perception or longer retention of the blue light as compared with the red I cannot at present say, but I think it is independent of the intensities.

C. E. STromeyer.

\section{Swifts.}

ON June 19, and again on June $2 \mathrm{r}$ last, in the evening, I watched a vast concourse of swifts flying over this town. They slowly soared upwards, shrieking and striking at each other, and at last went so far up in the sky as to look like a cloud of black gnats. I watched them till dusk, when their faint cries were still audible, and when these had diec away in the distance I waited long for the birds to descend, but they clid not, probably because they were old birds which had been sitting all day, and were glad of an opportunity to stretch their long wings in a few hours' flight. No great height would necessarily be attained by the birds during the short midsummer nights. I noticed on several subsequent evenings that at least some of the swifts of the town did not stay up till dusk; but I am not the less positive that on June 19 and $2 \mathrm{r}$ they spent the night in the sky.

Stroud. C. B. Witchell.

\section{Note on a Madras Micrococcus.}

THE sole charge of a Presidential Museum and the study of that high.road to pathological eminence, bacteriology, are unfortunately not compatible, but I have not been able to resist the rough investigation of a phenomenon which stands prominently out before my eyes as I write. It consists of a thin, homogeneous, pale pink pellicle, covering the chunam (shelllime) walls of my house on the side exposed to the heavy monsoon rain, which is at present varying the monotony of our "fine sunny days," which so impress our energetic coldweather visitors, who learn all about India from Calcutia to Cape Comorin in a three week' tour. So evenly is the pinkcoloured material distributed in my library, that its walls look as if they had been painted on one side, and whitewashed on the other three sides. This coloration, which is well known in Madras, is, I believe, commonly attributed to some occult chemical action on the lime, but a cover-glass specimen stained with methylene blue, and examined with a $\frac{1}{8}$-inch objective, decides at a glance that it is caused by a Micrococcus, which, in its microscopical appearance, presents nothing remarkable.

The mode of growth of this organism on or in artificial nutrient media I have not attempted to investigate, but $\mathrm{I}$ notice that white lead does not agree with it, as it -growth ceases abruptly at the painted framework of the doors and windows.

As I cannot find any description, in the reference-books at my disposal, of a Micrococcus which corresponds to the one here described, I christen it provisionally Micrococcus madraspatanus, Madraspatan being the old name of Madras, which is, according to Lassen, a corruption of Manda-rājya, meaning "realm of the stupid."

Government Central Museum, Madras, October 26.

\section{Catharinea undulata.}

IN October I886 I found, in Hertfordshire, two specimens of Catharinea unculata, Web. et Mohr., bearing fruit in the axils of the leaves; those specimens I unfortunately lost.

When this summer in Norway, I had the good fortune and pleasure of meeting Prof. S. O. Lindberg, of Helsingfors, and I mentioned the fact of the discovery to him. He then told rne that similar specimens had been found in Norway some little time before, and described under the name of $C$. anomola, Lindberg and Bryhn. In consequence of my conversation with Prof. Lindberg I looked again this autumn for specimens similar to those I had found last year, and after some little search I found some half-dozen or so near the same spot where I had found them last year.

The specimens I now have in my possession bear fruit at the apex of the stem, and also one, or sometimes two, setæ in axils of leaves below the apex. These pleurocarpous setæe differ from the acrocarpous by being twisted in a spiral manner, not being straight as the acrocarpous fruits are; they are inserted in a vaginula in the axil of the leaf, without any perichrtial leaves.

I : hould be glad if bryologists generally would look ont for specimens of this form. I should also consider it a great favour if any collectors who may find specimens would let me know, and provide me with an accurate description, or send me the specimens for inspection. Specimens should be preserved in strong methylated spirit, otherwise it may be difficult to verify some important cletails.

There is a brief reference to the Norwegian specimens in the Botanische Centralblalt, Band xxix. p. 2, 1887 ; the full description is, I believe, to be found in the Botaniska No:iser, I $886, \mathrm{p}$. I 57 ; the latter I have not yet been able to obtain access to, though I hope to do so soon.

Botanical I aboratory, Cambridge, November i 8 . 